\title{
Suppression of Matrix Metalloproteinase Production in Nasal Fibroblasts by Tranilast, an Antiallergic Agent, In Vitro
}

\author{
Toshiyuki Shimizu, ${ }^{1}$ Kenichi Kanai, ${ }^{1}$ Kazuhito Asano, ${ }^{2}$ Tadashi Hisamitsu, ${ }^{2}$ and Harumi Suzaki ${ }^{1}$ \\ ${ }^{1}$ Department of Otolaryngology, School of Medicine, Showa University, Tokyo 142-8666, Japan \\ ${ }^{2}$ Department of Physiology, School of Medicine, Showa University, Tokyo 142-8555, Japan
}

Received 3 February 2005; accepted 14 March 2005

\begin{abstract}
Allergic rhinitis is an inflammatory disease characterized by nasal wall remodeling with intense infiltration of eosinophils and mast cells/basophils. Matrix metalloproteinases (MMPs), MMP-2 and MMP-9, are the major proteolytic enzymes that induce airway remodeling. These enzymes are also important in the migration of inflammatory cells through basement membrane components. We evaluated whether tranilast (TR) could inhibit MMP production from nasal fibroblasts in response to tumor necrosis factor- $\alpha$ $(\mathrm{TNF}-\alpha)$ stimulation in vitro. Nasal fibroblasts (NF) were established from nasal polyp tissues taken from patients with allergic rhinitis. NF $\left(2 \times 10^{5}\right.$ cells $\left./ \mathrm{mL}\right)$ were stimulated with TNF- $\alpha$ in the presence of various concentrations of TR. After 24 hours, the culture supernatants were obtained and assayed for MMP-2, MMP-9, TIMP-1, and TIMP-2 levels by ELISA. The influence of TR on mRNA expression of MMPs and TIMPs in cells cultured for 12 hours was also evaluated by RT-PCR. TR at more than $5 \times$ $10^{-5} \mathrm{M}$ inhibited the production of MMP-2 and MMP-9 from NF in response to TNF- $\alpha$ stimulation, whereas TIMP-1 and TIMP-2 production was scarcely affected. TR also inhibited MMP mRNA expression in NF after TNF- $\alpha$ stimulation. The present data suggest that the attenuating effect of TR on MMP-2 and MMP-9 production from NF induced by inflammatory stimulation may underlie the therapeutic mode of action of the agent in patients with allergic diseases, including allergic rhinitis.
\end{abstract}

\section{INTRODUCTION}

Allergic rhinitis is defined as an inflammatory response in the nasal mucosa and is characterized by the clinical symptoms of sneezing, itching, congestion, rhinorrhea, and nasal blockage, which make breathing through the nose difficult $[1,2]$. Immunohistochemical studies of nasal tissues on patients with allergic rhinitis show the accumulation of eosinophils and basophils/mast cells within the lamina propria and epithelium [3]. Furthermore, nasal lavage also reveals the presence of numerous eosinophils in patients with allergic rhinitis [4].

Although the mechanisms of circulating inflammatory cell migration into the inflammatory sites are not fully understood, much evidence suggests that inflammatory cell adhesion and the degradation of extracellular matrix (ECM) proteins are essential processes for the cell recruitment [5]. The degradation of ECM proteins by inflammatory cells is accomplished, in part, by the secretion of matrix metalloproteinases (MMPs), like MMP-2 and

Correspondence and reprint requests to Harumi Suzaki, Department of Otolaryngology, School of Medicine, Showa University, Tokyo 142-8666, Japan; h-suzaki@med.showa-u.ac.jp
MMP-9, that specifically degrade denatured collagen, native type IV and type V collagens, and elastin [6, 7]. Furthermore, structural abnormalities such as fibrosis, thickening of the basement membrane, and sloughed-off epithelium with areas of epithelial metaplasia have been well described in patients with allergic rhinitis $[8,9]$. These pathological changes are called tissue remodeling and are caused by MMPs secreted from epithelial cells and fibroblasts in addition to infiltrating inflammatory cells $[9,10,11]$. These MMPs are also responsible for microvascular permeability leading to edema and cell migration and ECM remodeling at the site of inflammation $[7,10]$.

Several studies have demonstrated that corticosteroids, which are commonly used in the management of allergic airway diseases including allergic rhinitis, can decrease the expression and release of MMPs from airway epithelial cells and fibroblasts in vivo and in vitro $[12,13$, 14]. Fexofenadine hydrochloride, an H1-antihistamine, has also been reported to inhibit the production of MMPs from nasal fibroblasts at therapeutic blood levels in vitro [15]. In addition to this agent, drugs like tranilast (TR) and disodium cromoglycate, which exert membranestabilizing activities [16], have been used for the treatment and management of allergic diseases with remarkable success [17]. However, little information on the influence 
of membrane stabilizers on MMP production is available [18]. In the present study, we examined the effect of TR on MMP production in nasal fibroblasts (NF) in response to inflammatory stimulation in vitro.

\section{MATERIALS AND METHODS}

\section{Chemicals}

TR (Kissei Pharmaceutical Co Ltd, Matsumoto, Japan) as a preservative-free pure powder was dissolved in antibiotics-free RPMI-1640 medium (Sigma Chemicals, Co Ltd, St Louis, Mo) supplemented with 10\% heatinactivated fetal calf serum (RPMI-FCS; Flow Laboratories, North Ride, Australia) at $10^{-2} \mathrm{M}$. This solution was sterilized by passing through a $0.22 \mu \mathrm{m}$ filter and stored at $4^{\circ} \mathrm{C}$ as a stock solution. All dilutions used in this study were prepared from this stock solution. Recombinant TNF- $\alpha$ (preservative free) was purchased from Chemicon International, Inc (Temecula, Calif) and diluted with RPMI-FCS to produce a concentration of $50.0 \mathrm{ng} / \mathrm{mL}$.

\section{Induction of fibroblasts}

To induce fibroblasts from nasal polyps, five patients ( 3 female and 2 male; $36.6 \pm 9.4$ years of age) with allergic rhinitis were recruited at the Department of Otolaryngology Showa University Hospital. All subjects were nonsmokers and had not been treated with oral antiallergic agents for at least 2 months. Nasal polyps were obtained during surgical operations from five patients after obtaining their written informed consent. The study protocol was approved by the Ethics Committee of Showa University. The tissues were rinsed several times with RPMIFCS that contained $500 \mathrm{U}$ penicillin, $500 \mu \mathrm{g} / \mathrm{mL}$ streptomycin, and $5.0 \mu \mathrm{g} / \mathrm{mL}$ amphotericin B and were cut into small pieces (approximately $1 \mathrm{~mm}^{2}$ ). Diced specimens were plated at a density of 10 pieces in $100 \mathrm{~mm}$ tissue culture dishes and covered with a cover slip adhered to the dish with sterile vaseline. The dishes were then placed in a humidified atmosphere containing $5 \% \mathrm{CO}_{2}$ at $37^{\circ} \mathrm{C}$. When a monolayer of fibroblast-like cells reached confluence, the explanted tissues were removed. The cells were then trypsinized and replated at a concentration of $5 \times 10^{5}$ cells $/ \mathrm{mL}$ into $100 \mathrm{~mm}$ tissue culture dishes in a final volume of $10.0 \mathrm{~mL}$. The medium was changed every 3 days for 2-3 weeks until confluence was attained. Subsequently, the cells were split 1:2 at confluence and passaged $[19,20]$. The cells were characterized with antibodies against vimentine, cytokeratin, and fibronectin using fluorescent microscopy (model no IX 70, OLYMPUS Co Ltd, Tokyo, Japan) [20]. Fibroblast purity of the NF samples was more than $99 \%$. After characterization, aliquots of cells at each passage were frozen and stored in liquid nitrogen. Since previous experiments had revealed that the ability of cells to produce MMP-2, MMP-9, TIMP-1, and TIMP-2 in response to TNF- $\alpha$ stimulation was similar for 3 rd and 8 th passages of cells [15], 7th to 10th passage NF were used for the following experiments.

\section{Cell culture}

Fibroblasts were washed several times with RPMIFCS, introduced into each well of 24 -well culture plates in triplicate at a concentration of $2 \times 10^{5}$ cells $/ \mathrm{mL}$ in a volume of $1.0 \mathrm{~mL}$, and allowed to adhere for 2 hours. After removing unattached and dead cells by gently washing the wells with RPMI-FCS, TNF- $\alpha$ and various concentrations of TR were added to cell cultures simultaneously to give a final volume of $2.0 \mathrm{~mL}$. The cells were then cultured for 24 hours in a humidified atmosphere with $5 \% \mathrm{CO}_{2}$ at $37^{\circ} \mathrm{C}$. After 24 hours, the culture medium was removed and stored at $-40^{\circ} \mathrm{C}$ until use. To examine mRNA expression, the cells were cultured in a similar manner for 12 hours and stored at $-80^{\circ} \mathrm{C}$ until use. In another experiment, cells were treated with various concentrations of TR for 2 hours before the start of TNF- $\alpha$ stimulation; and the cells were cultured in a similar manner.

\section{Assay for MMP and TIMP}

MMP-2, MMP-9, TIMP-1, and TIMP-2 levels in the culture supernatants were assayed using commercially available human MMP and TIMP ELISA test kits (Amersham Biosciences, Bucks, UK) according to the manufacturer's recommendations. The activities of MMP-2 and MMP-9 in culture supernatants were also examined by ELISA test kits (Amersham Biosciences) according to the manufacturer's instructions. The results are expressed as the mean $\mathrm{ng} / \mathrm{mL} \pm$ standard error of duplicate assays for the five subjects.

\section{Assay for mRNA expression}

mRNA was extracted from NF using $\mu$ MACS mRNA isolation kits (Miltenyi Biotec $\mathrm{GmbH}$, Bergisch Gladbach, Germany), according to the manufacturer's instructions. The first-strand cDNA synthesis from $1.0 \mu \mathrm{g}$ mRNA was performed using the SuperScript Preamplification System for cDNA synthesis (Gibco BRL, Gaithersburg, $\mathrm{Md})$. The polymerase chain reaction (PCR) mixture consisted of $1.0 \mu \mathrm{L}$ of sample cDNA solution, $3.3 \mu \mathrm{L}$ of $10 \times$ PCR buffer (Takara Shuzo Co Ltd, Shiga, Japan), $2.6 \mu \mathrm{L}$ of dNTP mixture (Takara Shuzo), $1.0 \mu \mathrm{L}$ of both sense and antisense primers, $0.2 \mu \mathrm{L}$ of Taq DNA polymerase (Takara Shuzo), and distilled water to produce a final volume of $30 \mu \mathrm{L}$. The primers used for RT-PCR were $\quad 5^{\prime}$-AGATCTTCTTCTTCAAGGACCGGTT- $3^{\prime}$ (sense) and $5^{\prime}$-GGCTGGTCAGTGGCTTGGGGTA$3^{\prime}$ (antisense) for MMP-2, 5' CCCACATTTGACGTCCAGAGAAGAA- $3^{\prime}$ (sense) and $\quad 5^{\prime}$-GTTTTTGATGCTATTGGCTGAGATCCA$3^{\prime}$ (antisense) for MMP-9, $5^{\prime}$ CTCGCTGGACGTTGGAGGAAAGAA-3' (sense) and $5^{\prime}$-AGCCCATCTGGTACCTGTGGTTCA-3' (antisense) for TIMP-2, and 5' -CGGAACCGCTCATTGCC-3' and $5^{\prime}$-ACCCACACTGTGCCCATCTA- $3^{\prime}$ for $\beta$-actin [13]. The PCR conditions were as follows: 4 minutes at $94^{\circ} \mathrm{C}$, followed by 30 cycles of 30 seconds at $94^{\circ} \mathrm{C}, 30$ seconds at $58^{\circ} \mathrm{C}$, and 30 seconds at $72^{\circ} \mathrm{C}$. After cycling, 


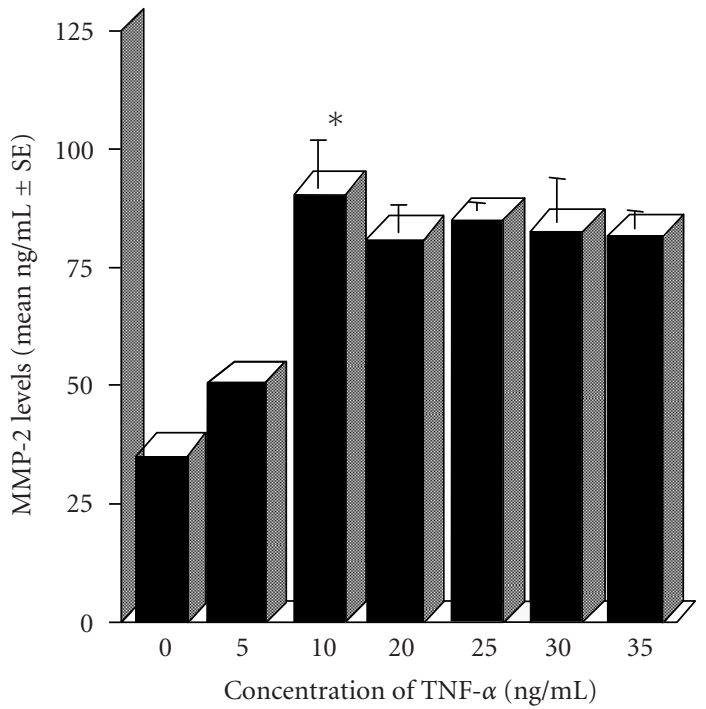

(a)

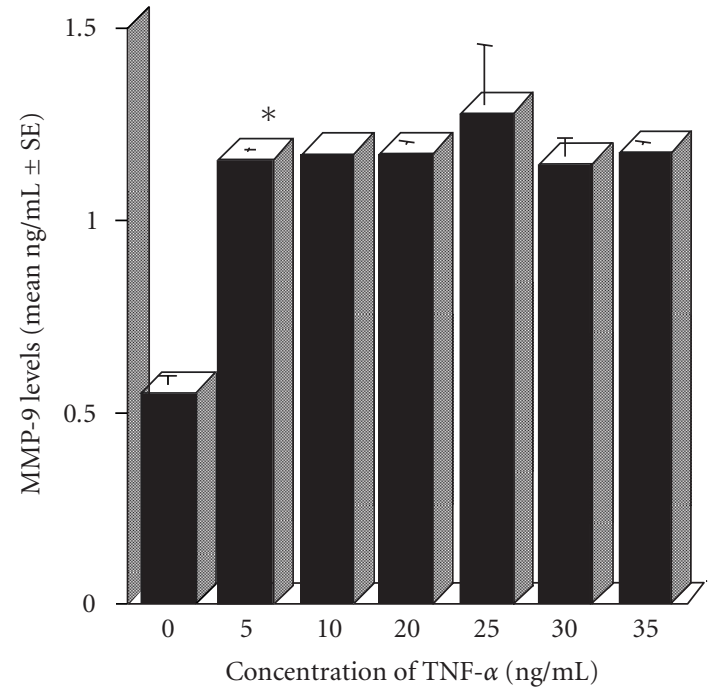

(b)

FIGURE 1. Influence of tumor necrosis factor- $\alpha$ (TNF- $\alpha$ ) on the production of (a) MMP-2 and (b) MMP-9 from nasal polyp fibroblasts. Cells were stimulated with various concentrations of TNF- $\alpha$ for 24 hours. MMP-2 and MMP-9 levels in the culture supernatants were examined by ELISA. Data are expressed as the mean $\mathrm{ng} / \mathrm{mL} \pm \mathrm{SE}$ of five different subjects. $*$ means significant $(P<.05)$ compared with 0 control.

there was a DNA extension period of 4 minutes at $72^{\circ} \mathrm{C}$ [13]. The primers used for RT-PCR of TIMP-1 were 5' -CACCCACAGACGGCCTTCTGCAAT-3' (sense) and 5'-AGTGTAGGTCTTGGTGAAGCC-3' (antisense) [21]. The PCR conditions were as follows: 4 minutes at $95^{\circ} \mathrm{C}$, followed by 35 cycles of 1 minute at $94^{\circ} \mathrm{C}, 1$ minute at $56^{\circ} \mathrm{C}$, and 1 minutes at $72^{\circ} \mathrm{C}$. After cycling, DNA was extended in a similar manner [21]. Each PCR product $(10 \mu \mathrm{L})$ was run on $3 \%$ agarose gels, visualized by UV illuminator after SYBR Green (BioWhittaker Molecular Applications, Rockland, Me) staining, and photographed. The intensity of the mRNA levels was corrected using the level of $\beta$-actin transcripts measured by a densitometer.

\section{Statistical analysis}

The statistical significance of the difference between the control and experimental data was analyzed using an ANOVA, followed by Fisher's PLSD test. A $P$ value less than .05 was considered statistically significant.

\section{RESULTS}

\section{Suppressive activity of TR on the production of MMP-2, MMP-9, TIMP-1, and TIMP-2 from NF}

The first set of experiments was designed to determine the optimum concentration of TNF- $\alpha$ required to obtain the maximum production of MMPs from NF. NF $\left(2 \times 10^{5}\right.$ cells $\left./ \mathrm{mL}\right)$ were stimulated with various concentrations of TNF- $\alpha$ for 24 hours. MMP-2 and MMP-9 levels in the culture supernatants were then assayed by ELISA. As shown in Figure 1a, the stimulation of NF with TNF$\alpha$ at more than $10.0 \mathrm{ng} / \mathrm{mL}$ (but not $5.0 \mathrm{ng} / \mathrm{mL}$ ) caused a significant increase in MMP-2 production. The ability of NF to produce MMP-9 was also enhanced by the stimulation of cells with TNF- $\alpha$. The minimum concentration of TNF- $\alpha$, causing a significant production of MMP9, was $5.0 \mathrm{ng} / \mathrm{mL}$ (Figure $1 \mathrm{~b}$ ). We then examined the influence of TR on MMP production from NF stimulated with TNF- $\alpha$. The addition of TR at less than $2.5 \times 10^{-5} \mathrm{M}$ did not cause the suppression of MMP-2 production from NF, which was increased by TNF- $\alpha$ stimulation. When TR was added at concentrations of $5.0 \times 10^{-5} \mathrm{M}$ or higher, however, the ability of cells to produce MMP-2 after TNF$\alpha$ stimulation was significantly suppressed Figure $2 \mathrm{a}$. We further examined the influence of TR on MMP-9 production from NF. As shown in (Figure 2b), low doses (0.5 and $\left.2.5 \times 10^{-5} \mathrm{M}\right)$ of TR did not affect MMP-9 production from NF stimulated with TNF- $\alpha$ : MMP-9 levels in the experimental culture supernatants were nearly identical (not significant) to those in the control supernatants (TNF alone). However, the addition of TR at concentrations of $5.0 \times 10^{-5} \mathrm{M}$ or higher significantly inhibited MMP-9 production from NF induced by TNF- $\alpha$ stimulation (Figure $2 \mathrm{~b}$ ). The data in Figures $2 \mathrm{c}$ and $2 \mathrm{~d}$ also show that TR at more than $5.0 \times 10^{-5} \mathrm{M}$ could significantly suppress the activity of MMP-2 and MMP-9 in culture supernatants. The fourth experiment was undertaken to examine the influence of TR on TIMP-1 and TIMP-2 


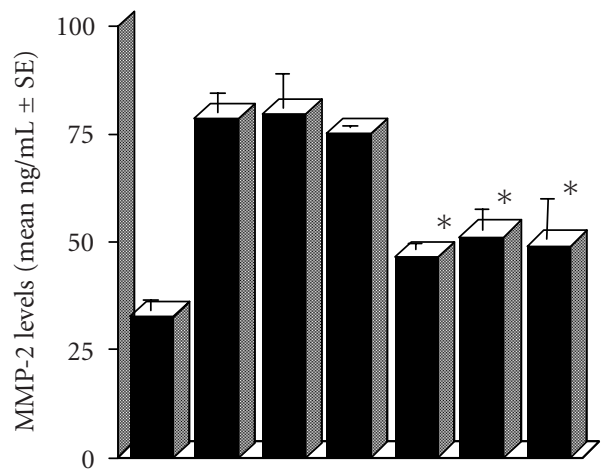

(a)

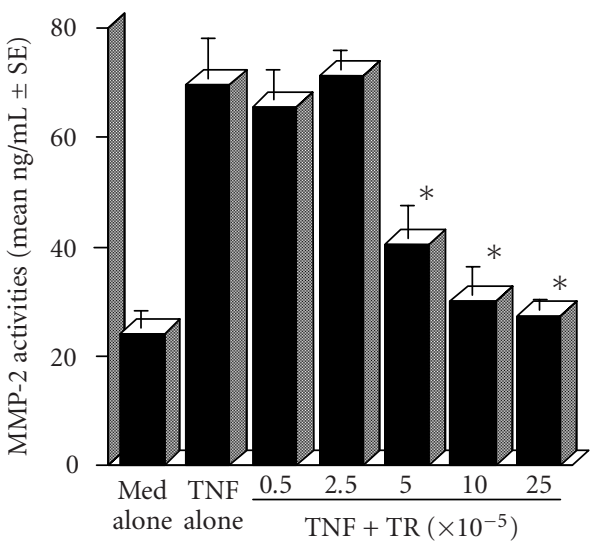

(c)

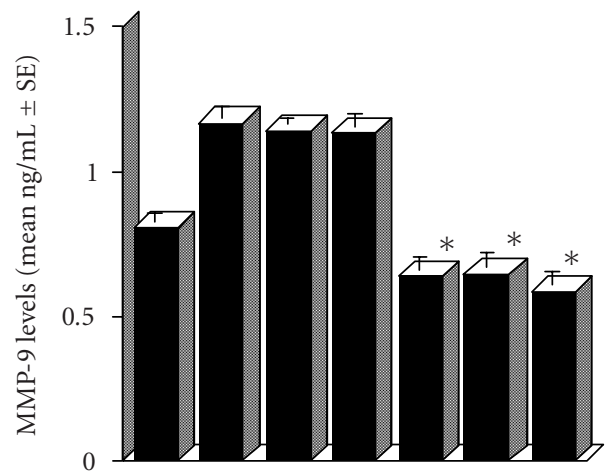

(b)

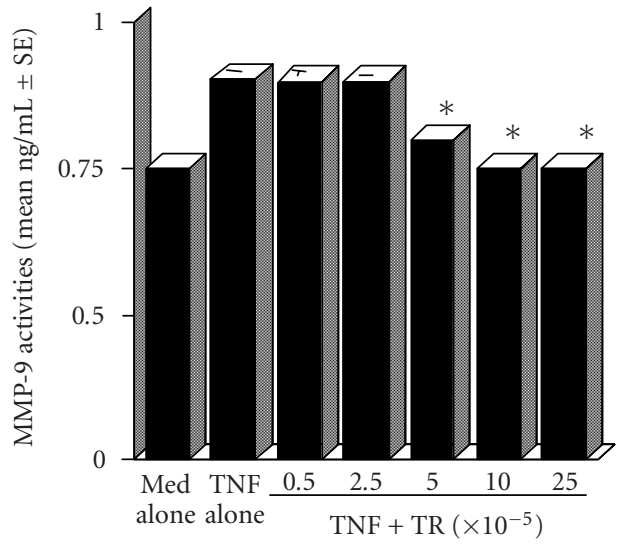

(d)

FIGURE 2. Influence of tranilast (TR) on the production of MMP-2 and MMP-9 from nasal fibroblasts in response to TNF- $\alpha$ stimulation and on their activities. Cells were stimulated with $10.0 \mathrm{ng} / \mathrm{mL}$ TNF in the presence of various concentrations of TR for 24 hours. Data are expressed as the mean $\mathrm{ng} / \mathrm{mL} \pm \mathrm{SE}$ of five different subjects. (a) MMP-2 levels; (b) MMP-9 levels; (c) MMP-2 activities. (d) MMP-9 activities. $*$ means significant $(P<.05)$ compared with TNF alone.

production from NF. The data in Figure 3 clearly show that addition of TR to cell cultures stimulated with TNF- $\alpha$ suppressed the production of both TIMP-1 and TIMP-2, when the cells were treated with the agent at $25.0 \times 10^{-5} \mathrm{M}$. However, lower doses of TR (less than $10.0 \times 10^{-5} \mathrm{M}$ ) could not exert suppressive effect on TIMP-1 and TIMP-2 production (Figure 3 ). We finally examined whether pretreatment of cells with TR could also suppress the production of MMPs and TIMPs from NF induced by TNF- $\alpha$ stimulation. As shown in Figures $4 \mathrm{a}$ and $4 \mathrm{~b}$, pre-treatment with TR could suppress the production of MMP-2 and MMP-9; and the significant suppression was firstly noted at $5.0 \times 10^{-5} \mathrm{M}$. The data in Figures $4 \mathrm{c}$ and $4 \mathrm{~d}$ also show that pre-treatment with TR at more than $5.0 \times 10^{-5} \mathrm{M}$ caused significant suppression of MMP-2 and MMP-9 activities in culture supernatants. However, TR at $5 \times$ $10^{-5} \mathrm{M}$ could not inhibit TIMP- 1 and TIMP-2 production from NF (Figure 5). The suppressive activity of TR on TIMP-1 and TIMP-2 production was only observed when the cells were pre-treated with TR at $25.0 \times 10^{-5} \mathrm{M}$ (Figure 5).

\section{Influence of TR on MMP and TIMP mRNA expression in nasal fibroblasts}

An additional set of experiments was performed to examine possible mechanisms enabling TR to suppress MMP-2 and MMP-9 production, but not TIMP-1 and TIMP-2 production from NF stimulated with TNF- $\alpha$. Cells were cultured with $25.0 \mathrm{ng} / \mathrm{mL}$ TNF- $\alpha$ in the presence of either $0,2.5$, or $5.0 \times 10^{-5} \mathrm{M}$ TR for 12 hours. The levels of mRNA expression were then evaluated by RT-PCR. Addition of TR at more than $5.0 \times 10^{-5} \mathrm{M}$ significantly suppressed the TNF- $\alpha$-induced enhancement in MMP mRNA expression in NF (Figure 6). However, TR did not reduce the levels of TIMP mRNA expression in NF (Figure 7). These findings were confirmed by graphs showing the ratio of the target to the $\beta$-actin mRNA expression level. 


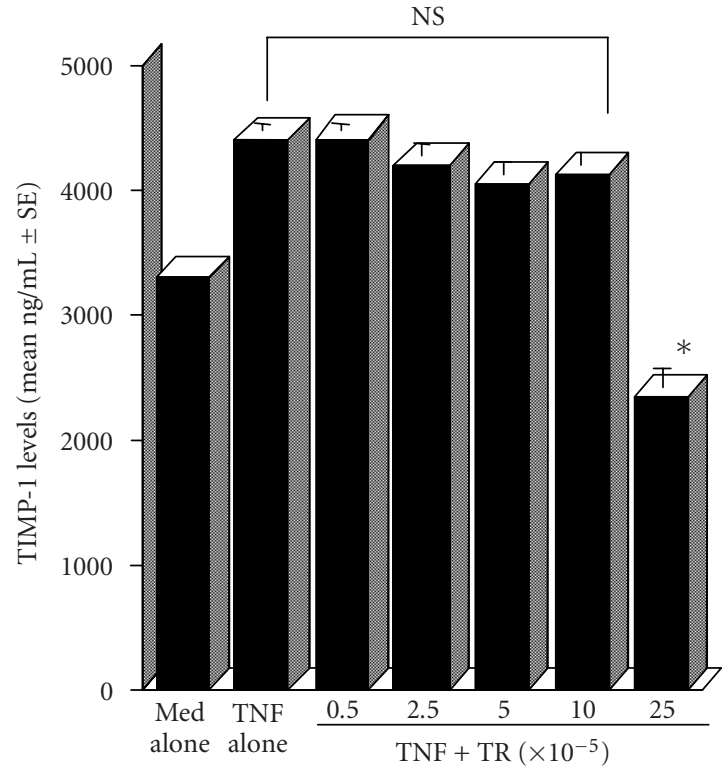

(a)

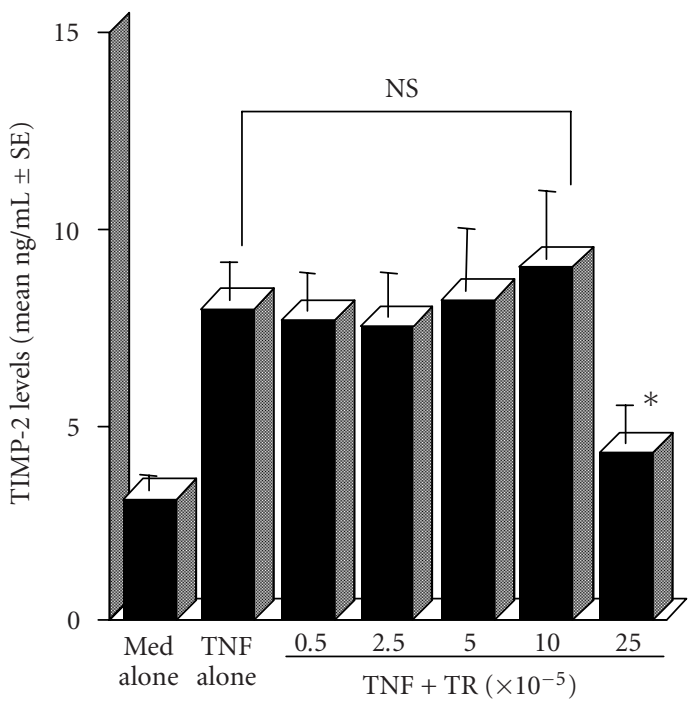

(b)

FIGURE 3. Influence of tranilast (TR) on the production of TIMP-1 and TIMP-2 from nasal fibroblasts in response to TNF- $\alpha$ stimulation. Cells were stimulated with $10.0 \mathrm{ng} / \mathrm{mL}$ TNF in the presence of various concentrations of TR for 24 hours. Data are expressed as the mean $\mathrm{ng} / \mathrm{mL} \pm \mathrm{SE}$ of five different subjects. NS means not significant $(P>.05)$; $*$ means significant $(P<.05)$ compared with TNF alone.

\section{DISCUSSION}

In the present study, we clearly demonstrated that TR at $5.0 \times 10^{-5} \mathrm{M}$, which is lower than therapeutic tissue levels [21], could inhibit the production of both MMP-2 and MMP-9 from NF with virtually no effects on the production of TIMP-1 and TIMP-2. In addition, this inhibitory action of TR on MMP production is due, at least in part, to its suppressive activity on MMP mRNA expression.

Allergic rhinitis is an inflammatory disorder of the nasal mucosa and epithelium $[1,2,3,11]$. Aeroallergen exposure in patients with allergic rhinitis results in immune cell activation within the nasal mucosa along with activation of the resident epithelial and endothelial cells $[22,24]$. Structural changes within the nasal walls, in addition to classical inflammatory responses, have also been reported in patients with allergic rhinitis. These structural changes include epithelial disruption, mucus gland hypertrophy, enhanced mucosal collagen deposition, mucosal myofibroblast transformation, and increased matrix protein deposition. These cellular events are now called tissue remodeling and involve extensive alteration of tissue ECM $[8,9]$. ECM is involved in tissue homeostasis and several pathologic conditions such as tumor invasion, wound healing, and inflammation. Two groups of proteins, MMPs, and their counterregulatory inhibitors, TIMPs, are important factors for the maintenance of ECM homeostasis. The MMPs are a large family of $\mathrm{Ca}^{2+}$ activated, $\mathrm{Zn}^{2+}$-dependent endopeptidases that have the ability to degrade various components of the ECM and basement membrane $[11,23]$. At least 23 members of the MMP family have been characterized [11, 23]. Among them, MMP-2 and MMP-9, also known as gelatinase A and $\mathrm{B}$, respectively, degrade basement membrane type IV and type $\mathrm{V}$ collagen and denatured collagens $[11,23]$. They can also degrade elastine, as they can also act as elastases $[11,23]$. These MMPs are produced by numerous cell types, including fibroblasts, macrophages, and eosinophils and mediate the transmigration of inflammatory cells through the basement membrane to propagate inflammation [12, 24]. MMPs are also responsible for microvasular permeability leading to edema and enhanced cell migration [12]. The findings of these reports suggest that the attenuating effect of TR on MMP-2 and MMP-9 production from NF induced by inflammatory stimulation may underlie the clinical efficacy of this therapeutic agent in allergic diseases, including allergic rhinitis. The activity of MMPs in the extracellular milieu is controlled by specific and potent inhibitory proteins known as TIMPs [25]. The present results clearly showed that TR did not inhibit TIMP-1 and TIMP-2 production from NF in response to TNF- $\alpha$ stimulation, suggesting that MMPs secreted in small amounts during TR treatment are inactivated by TIMP-1 and TIMP-2, and resulted in the favorable modification of clinical symptoms arising from ECM remodeling in patientsd with allergic rhinitis. The administration of MMP inhibitor into mice reportedly reduces the migration of inflammatory cells through the 


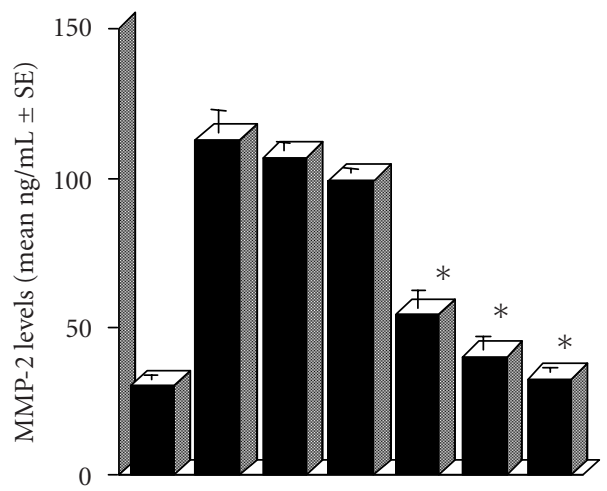

(a)

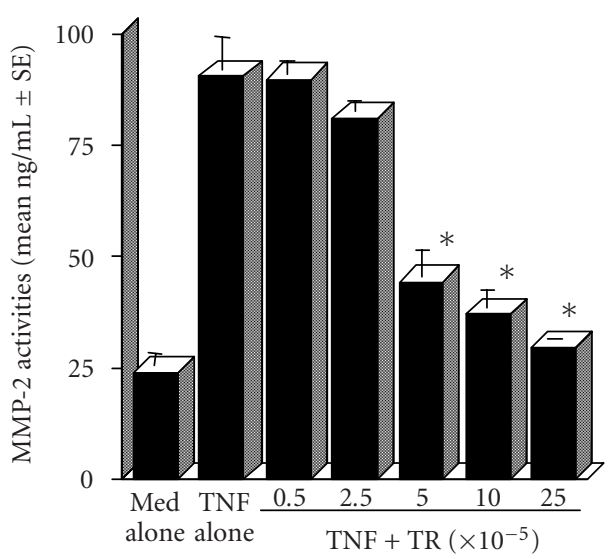

(c)

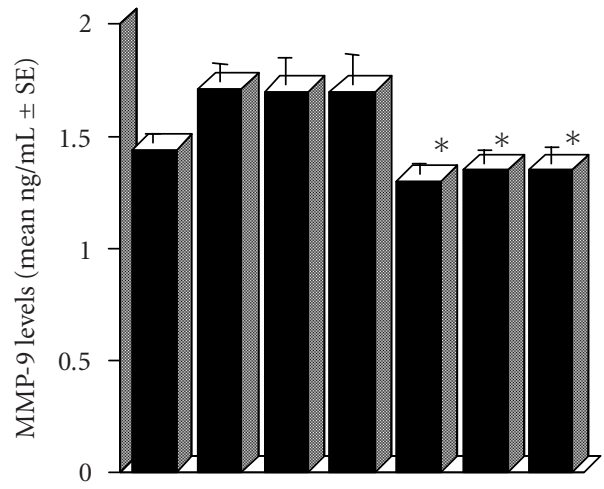

(b)

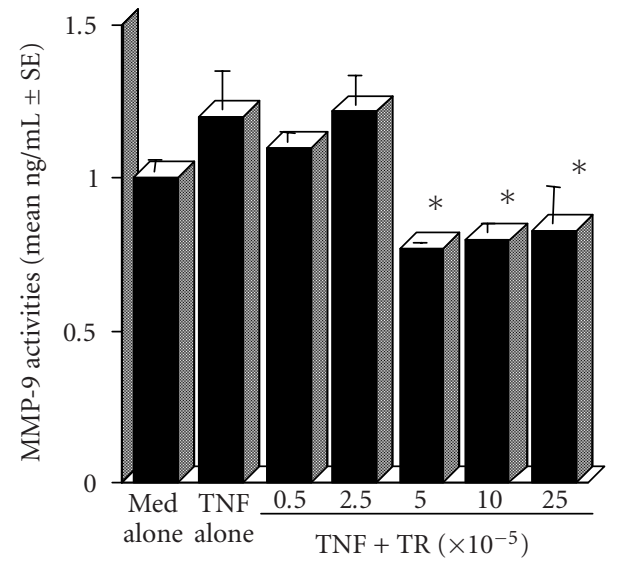

(d)

FiguRE 4. Influence of pretreatment of nasal fibroblast with tranilast (TR) on the production of MMP-2 and MMP-9 and their activities. Cells were treated with various concentrations of TR for 2 hours and then stimulated with TNF- $\alpha$ (TNF) for 24 hours. Data are expressed as the mean $\mathrm{ng} / \mathrm{mL} \pm \mathrm{SE}$ of five different subjects. $*$ means significant $(P<.05)$ compared with TNF alone.

endothelial and epithelial basement membrane [26]. This inhibitory action of the MMP inhibitor on cell migration has been associated with its suppressive effect on the expression of the adhesion molecules, ICAM-1 and VCAM1 [5], which are essential for cell migration into inflammatory tissues. These reports suggest that the negative suppressive effect of TR on TIMP-1 and TIMP-2 production may contribute, at least in part, to the modification of clinical symptoms, when TR is given to patients with allergic rhinitis.

TNF- $\alpha$ is well known as a multifunctional cytokine that plays a role in inflammation, immunity, and a variety of diseases. It is also accepted that TNF- $\alpha$ activates several components implicated in cellular signal transduction. Binding of TNF- $\alpha$ to type 1 TNF receptor causes an increase in intracellular $\mathrm{Ca}^{2+}$ concentrations through calcium influx [27], resulting in the activation of transcriptional factors (NF- $\kappa$ B and AP-1), which are essential for
MMP production [28, 29]. TR has been reported to inhibit increases in cellular $\mathrm{Ca}^{2+}$ concentrations through the suppression of $\mathrm{Ca}^{2+}$ influx from the extracellular space [30]. Judging from these reports, it seems reasonable to speculate that TR may suppress $\mathrm{Ca}^{2+}$ influx into NF stimulated with TNF- $\alpha$, thereby inhibiting the activation of the transcriptional factors (NF- $\kappa \mathrm{B}$ and AP-1) responsible for inducing MMP mRNA expression. The present observations showing that MMP mRNA expression in NF was suppressed by TR support this hypothesis.

Prostaglandins (PG), especially $\mathrm{PGE}_{1}$ and $\mathrm{PGE}_{2}$, have been reported to up regulate the production of MMPs in synoviocytes [31,32] and gingival fibroblasts [33] after inflammatory stimulation in vitro. PGs are also involved in the production of MMPs from human pulp cells [34] and prostate epithelial tumor cells [35]. The finding that TR inhibited MMP-2 and MMP-9 production suggests that prostaglandin-dependent mechanism(s) may be involved 


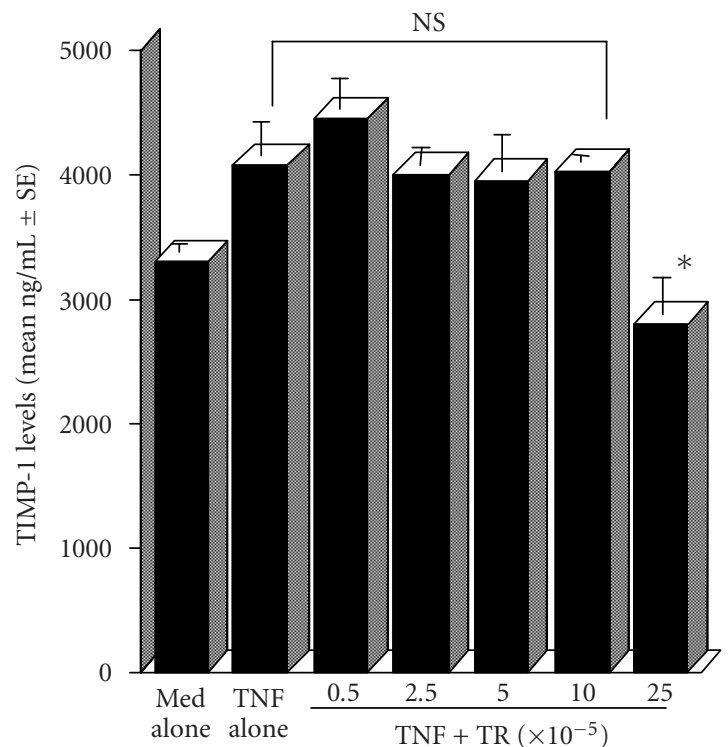

(a)

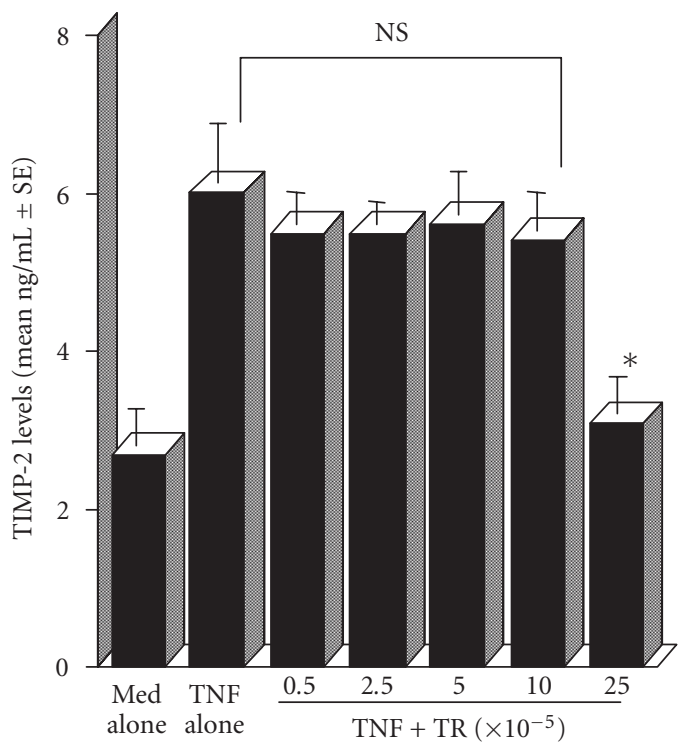

(b)

FIGURE 5. Influence of pretreatment of nasal fibroblasts with tranilast (TR) on the production of TIMP-1 and TIMP-2. Cells were treated with various concentrations of TR for 2 hours and then stimulated with TNF- $\alpha$ (TNF) for 24 hours. Data are expressed as the mean $\mathrm{ng} / \mathrm{mL} \pm \mathrm{SE}$ of five different subjects. NS means not significant $(P>.05) ; *$ means significant $(P<.05)$ compared with TNF alone.

MMP-2
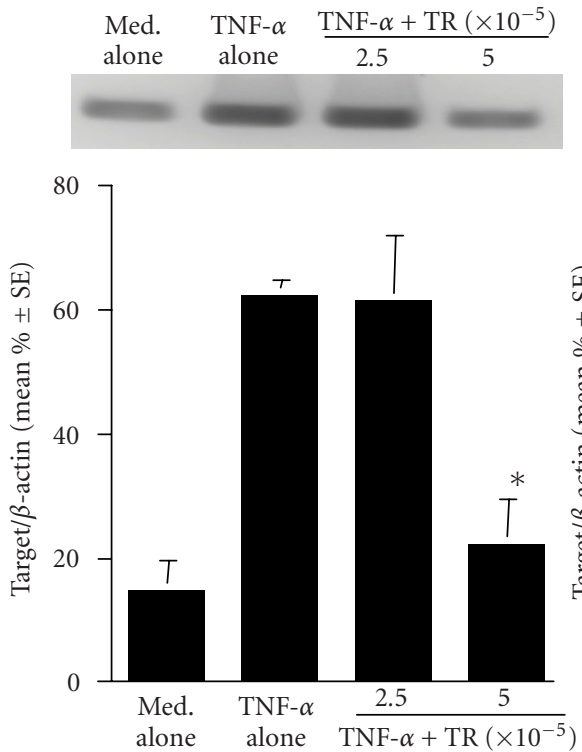

(b)
MMP-9

Med. TNF- $\alpha$ TNF- $\alpha+\operatorname{TR}\left(\times 10^{-5}\right)$ alone alone $\frac{}{2.5} \quad 5$
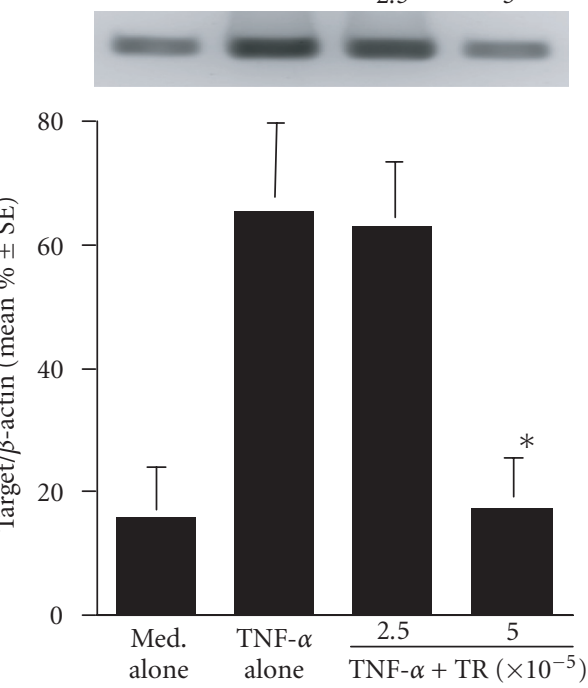

(c)

FIGURE 6. Influence of tranilast (TR) on mRNA expression of (b) MMP-2 and (c) MMP-9 in nasal polyp fibroblasts after TNF- $\alpha$ stimulation. Cells were stimulated with $10.0 \mathrm{ng} / \mathrm{mL}$ TNF- $\alpha$ in the presence of various concentrations of TR for 12 hours. mRNA expression was examined by RT-PCR. One representative photograph out of five different subjects is shown. Densitometric analysis of the results of RT-PCR is shown with the intensity of MMP-2 and MMP-9. $*$ means significant $(P<.05)$ compared with TNF- $\alpha$ alone. 
TIMP-1
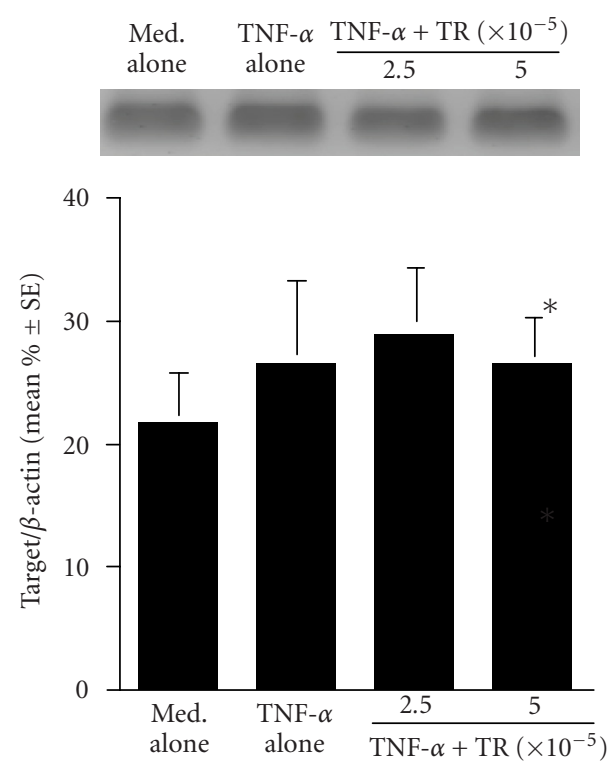

(a)
TIMP-2
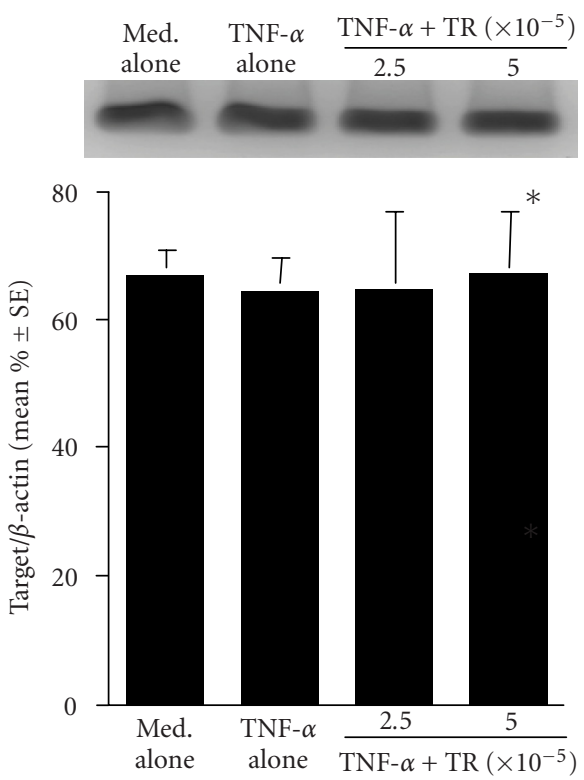

(b)

FIGURE 7. Influence of tranilast (TR) on mRNA expression of TIMP-1 and TIMP-2 in nasal polyp fibroblasts after TNF- $\alpha$ stimulation. Cells were stimulated with $10.0 \mathrm{ng} / \mathrm{mL}$ TNF- $\alpha$ in the presence of various concentrations of TR for 12 hours. mRNA expression was examined by RT-PCR. One representative photograph out of five different subjects is shown. Densitometric analysis of the results of RT-PCR is shown with the intensity of MMP-2 and MMP-9. $\beta$-actin mRNA expression was shown in Figure 6 . $*$ means not significant $(P<.05)$ compared with TNF- $\alpha$ alone.

in MMP production in NF induced by TNF- $\alpha$ stimulation, since TR is reported to decrease $\mathrm{PGE}_{2}$ formation in monocytes after inflammatory stimulation [36].

It has been reported that TR decreased the ability of a human fibroblast cell line from gastric carcinoma, to produce MMP-2, but not MMP-9 in response to transforming growth factor- $\beta$ in vitro, even when the agent at $3 \times 10^{-5} \mathrm{M}$ was added to cell cultures [37]. The reasons for the discrepancy between this report and our data are not clear at present. The different cell sources of nasal polyps and gastric carcinoma may be responsible for this phenomenon, because the biological characteristics of fibroblasts from different tissues were reported to be quite different $[38,39]$.

Since the concentration of TR that suppressed MMP-2 and MMP-9 production in vitro $\left(5.0 \times 10^{-5} \mathrm{M}\right)$ was equivalent to that in therapeutic tissue levels [21], the efficacy of TR in allergic inflammatory diseases might be explained by these in vitro data suggesting that TR down regulates fibroblast functions related to inflammation and tissue remodeling.

\section{ACKNOWLEDGMENT}

We thank KISSEI Pharmaceuticals Co Ltd (Matsumoto, Japan) for kind donation of tranilast.

\section{REFERENCES}

[1] Howarth PH. Disease pathogenic mechanisms in allergy: a rational basis for treatment. BMJ. 1998;316:757-761.

[2] Howarth PH, Salagean M, Dokic D. Allergic rhinitis: not purely a histamine-related disease. Allergy. 2000;55(suppl 64):7-16.

[3] Bentley AM, Jacobson MR, Cumberworth V, et al. Immunohistology of the nasal mucosa in seasonal allergic rhinitis: increases in activated eosinophils and epithelial mast cells. J Allergy Clin Immunol. 1992;89(4):877-883.

[4] Wilson S, Lau L, Howarth PH. Inflammatory mediators in naturally occurring rhinitis. Clin Exp Allergy. 1998;28(2):220-227.

[5] Lee KS, Jin SM, Kim HJ, Lee YC. Matrix metalloproteinase inhibitor regulates inflammatory cell migration by reducing ICAM-1 and VCAM-1 expression in a murine model of toluene diisocyanate-induced asthma. J Allergy Clin Immunol. 2003;111(6):12781284.

[6] Okada Y, Gonoji Y, Naka K, et al. Matrix metalloproteinase 9 (92-kDa gelatinase/type IV collagenase) from HT 1080 human fibrosarcoma cells. Purification and activation of the precursor and enzymic properties. J Biol Chem. 1992;267(30):21712-21719. 
[7] Lechapt-Zalcman E, Coste A, d'Ortho MP, et al. Increased expression of matrix metalloproteinase- 9 in nasal polyps. J Pathol. 2001;193(2),233-241.

[8] Calderon MA, Lozewicz S, Prior A, Jordan S, Trigg CJ, Davies RJ. Lymphocyte infiltration and thickness of the nasal mucous membrane in perennial and seasonal allergic rhinitis. J Allergy Clin Immunol. 1994;93(3):635-643.

[9] Salib RJ, Howarth PH. Remodelling of the upper airways in allergic rhinitis: is it a feature of the disease? Clin Exp Allergy. 2003;33(12):1629-1633.

[10] Hoshino M, Nakamura Y, Sim JJ, Shimoji J, Isogai S. Bronchial subepithelial fibrosis and expression of matrix metalloproteinase- 9 in asthmatic airway inflammation. J Allergy Clin Immunol. 1998;102(5):783-788.

[11] Shaida A, Kenyon G, Devalia J, Davies RJ, MacDonald TT, Pender SL. Matrix metalloproteinases and their inhibitors in the nasal mucosa of patients with perennial allergic rhinitis. J Allergy Clin Immunol. 2001;108(5):791-796.

[12] Hoshino M, Takahashi M, Takai Y, Sim J. Inhaled corticosteroids decrease subepithelial collagen deposition by modulation of the balance between matrix metalloproteinase-9 and tissue inhibitor of metalloproteinase- 1 expression in asthma. J Allergy Clin Immunol. 1999;104(pt 1):356-363.

[13] Namba M, Asano K, Kanai K, et al. Suppression of matrix metalloproteinase production from nasal fibroblasts by fluticasone propionate in vitro. Acta Otolaryngol. 2004;124(8):964-969.

[14] Valencia AM, Beharry KD, Ang JG, et al. Early postnatal dexamethasone influences matrix metalloproteinase-2 and -9 , and their tissue inhibitors in the developing rat lung. Pediatr Pulmonol. 2003;35(6):456-462.

[15] Asano K, Kanai KI, Suzaki H. Suppressive activity of fexofenadine hydrochloride on metalloproteinase production from nasal fibroblasts in vitro. Clin Exp Allergy. 2004;34(12):1890-1898.

[16] Bissonnette EY, Enciso JA, Befus AD. Inhibition of tumour necrosis factor-alpha (TNF- $\alpha$ ) release from mast cells by the anti-inflammatory drugs, sodium cromoglycate and nedocromil sodium. Clin Exp Immunol. 1995;102(1):78-84.

[17] Ito J, Asano K, Tryka E, et al. Suppressive effects of co-stimulatory molecule expressions on mouse splenocytes by anti-allergic agents in vitro. Mediators Inflamm. 2000;9(2):69-75.

[18] Maita E, Sato M, Yamaki K. Effect of tranilast on matrix metalloproteinase-1 secretion from human gingival fibroblasts in vitro. J Periodontol. 2004;75(8):1054-1060.

[19] Kanai K, Asano K, Hisamitsu T, Suzaki H. Suppression of matrix metalloproteinase production from nasal fibroblasts by macrolide antibiotics in vitro. Eur Respir J. 2004;23(5):671-678.

[20] Suzaki H, Asano K, Yu M, Hisamitsu T. Influence of roxithromycin on inflammatory cytokine production from nasal polyp fibroblasts in vitro. Acta Otolaryngol. 2003;123(5):637-642.

[21] Suzawa H, Kikuchi S, Ichikawa K, et al. Effect of tranilast, an anti-allergic drug, on the human keloid tissues. Nippon Yakurigaku Zasshi. 1992;99(4):231239.

[22] Simons FE. $\mathrm{H}_{1}$-antihistamines: more relevant than ever in the treatment of allergic disorders. J Allergy Clin Immunol. 2003;112(suppl 4):S42-52.

[23] Docherty AJ, Murphy G. The matrix metalloproteinases and their inhibitors. Am J Respir Cell Mol Biol. 1992;7(2):120-125.

[24] Baroody FM, Lim MC, Proud D, Kagey-Sobotka A, Lichtenstein LM, Naclerio RM. Effects of loratadine and terfenadine on the induced nasal allergic reaction. Arch Otolaryngol Head Neck Surg. 1996;122(3):309-316.

[25] Nagase H. Activation mechanisms of matrix metalloproteinases. Biol Chem. 1997;378(3-4):151-160.

[26] Lee YC, Song CH, Lee HB, et al. A murine model of toluene diisocyanate-induced asthma can be treated with matrix metalloproteinase inhibitor. J Allergy Clin Immunol. 2001;108(6):1021-1026.

[27] Lazaar AL, Amrani Y, Hsu J, et al. Cd40-mediated signal transduction in human airway smooth muscle. J Immunol. 1998;161(6):3120-3127.

[28] Sato H, Seiki M. Regulatory mechanism of $92 \mathrm{kDa}$ type IV collagenase gene expression which is associated with invasiveness of tumor cells. Oncogene. 1993;8(2):395-405.

[29] Okamoto S, Mukaida N, Yasumoto K, et al. The interleukin-8 AP-1 and $\kappa$ B-like sites are genetic end targets of FK506-sensitive pathway accompanied by calcium mobilization. J Biol Chem. 1994;269(11):8582-8589.

[30] Ishibashi S, Ikeda U, Ihara T, Shimada K. Tranilast inhibits contraction and $\mathrm{Ca}^{2+}$ movement of porcine coronary arteries. Atherosclerosis. 1997;130(12):113-119.

[31] DiBattista JA, Martel-Pelletier J, Fujimoto N, Obata K, Zafarullah M, Pelletier JP. Prostaglandins E2 and E1 inhibit cytokine-induced metalloprotease expression in human synovial fibroblasts. Mediation by cyclic-AMP signalling pathway. Lab Invest. 1994;71(2):270-278.

[32] Pillinger $\mathrm{MH}$, Rosenthal PB, Tolani SN, et al. Cyclooxygenase-2-derived E prostaglandins downregulate matrix metalloproteinase-1 expression in fibroblast-like synoviocytes via inhibition of extracellular signal-regulated kinase activation. J Immunol. 2003;171(11):6080-6089.

[33] Domeij H, Yucel-Lindberg T, Modeer T. Signal pathways involved in the production of MMP-1 and MMP-3 in human gingival fibroblasts. Eur J Oral Sci. 2002;110(4):302-806.

[34] Huang FM, Yang SF, Hsieh YS, Liu CM, Yang LC, Chang YC. Examination of the signal transduction 
pathways involved in matrix metalloproteinases-2 in human pulp cells. Oral Surg Oral Med Oral Pathol Oral Radiol Endod. 2004;97(3):398-403.

[35] Attiga FA, Fernandez PM, Weeraratna AT, Manyak MJ, Patierno SR. Inhibitors of prostaglandin synthesis inhibit human prostate tumor cell invasiveness and reduce the release of matrix metalloproteinases. Cancer Res. 2000;60(16):4629-4637.

[36] Capper EA, Roshak AK, Bolognese BJ, et al. Modulation of human monocyte activities by tranilast, SB 252218, a compound demonstrating efficacy in restenosis. J Pharmacol Exp Ther. 2000;295(3):10611069.

[37] Yashiro M, Murahashi K, Matsuoka T, et al. Tranilast (N-3,4-dimethoxycinamoyl anthranilic acid): a novel inhibitor of invasion-stimulating interaction between gastric cancer cells and orthotopic fibroblasts. Anticancer Res. 2003;23(5A):3899-3904.

[38] Ma S, Fang RH, Chang WP. Heterogeneity in radiosensitivity of human diploid fibroblasts from keloids and normal skins. Cell Biol Int. 1996;20(4):289-292.

[39] Ali-Bahar M, Bauer B, Tredget EE, Ghahary A. Dermal fibroblasts from different layers of human skin are heterogeneous in expression of collagenase and types I and III procollagen mRNA. Wound Repair Regen. 2004;12(2):175-182. 


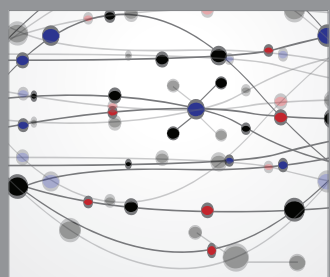

The Scientific World Journal
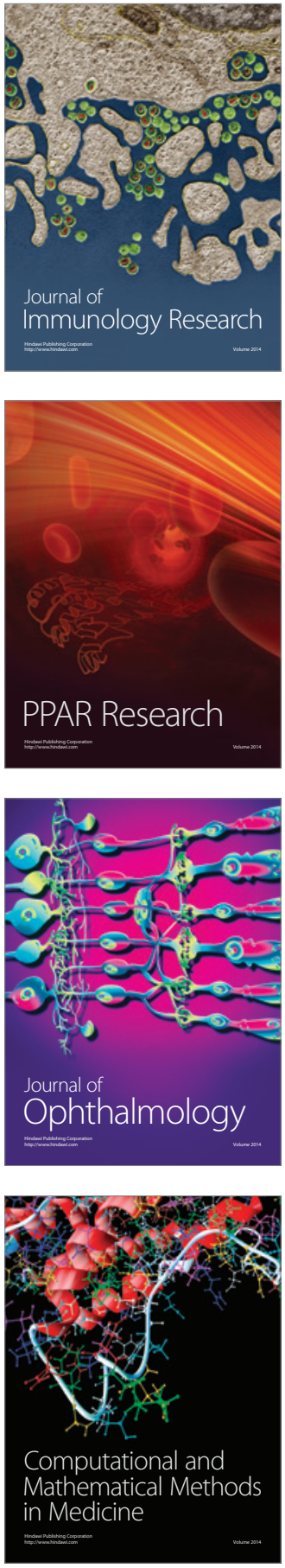

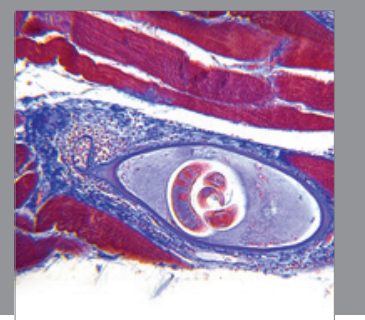

Gastroenterology

Research and Practice
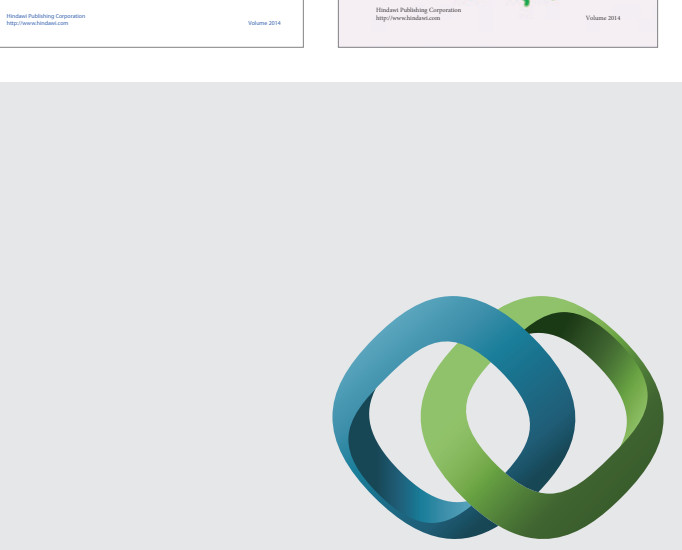

\section{Hindawi}

Submit your manuscripts at

http://www.hindawi.com
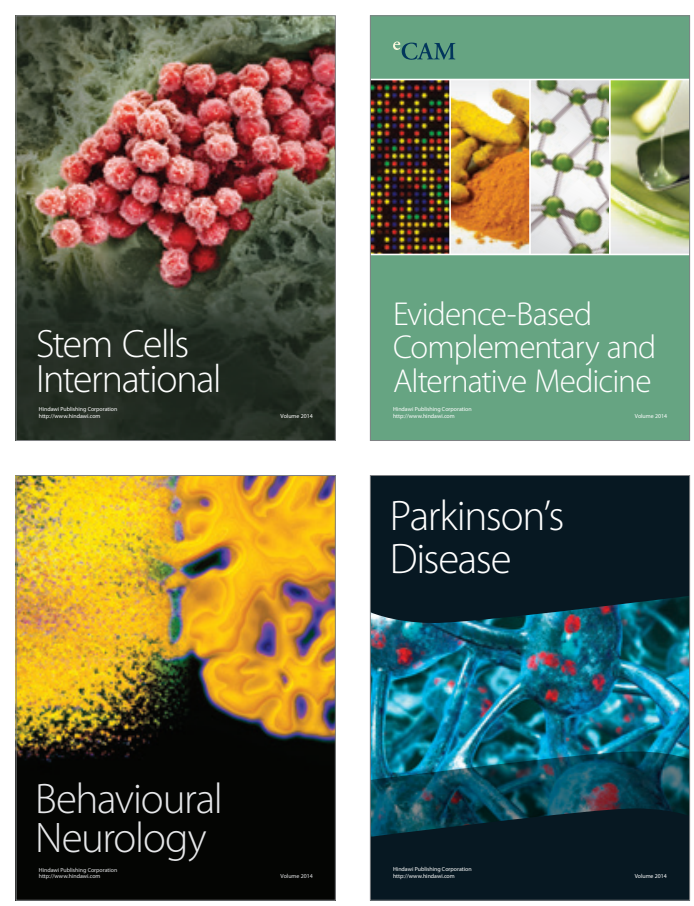

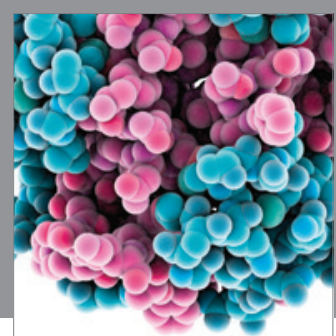

Journal of
Diabetes Research

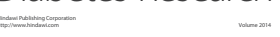

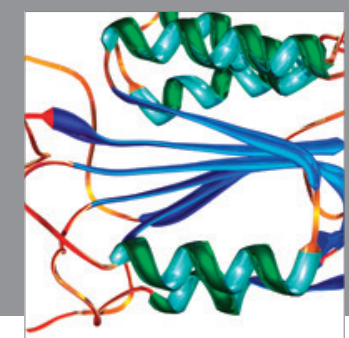

Disease Markers
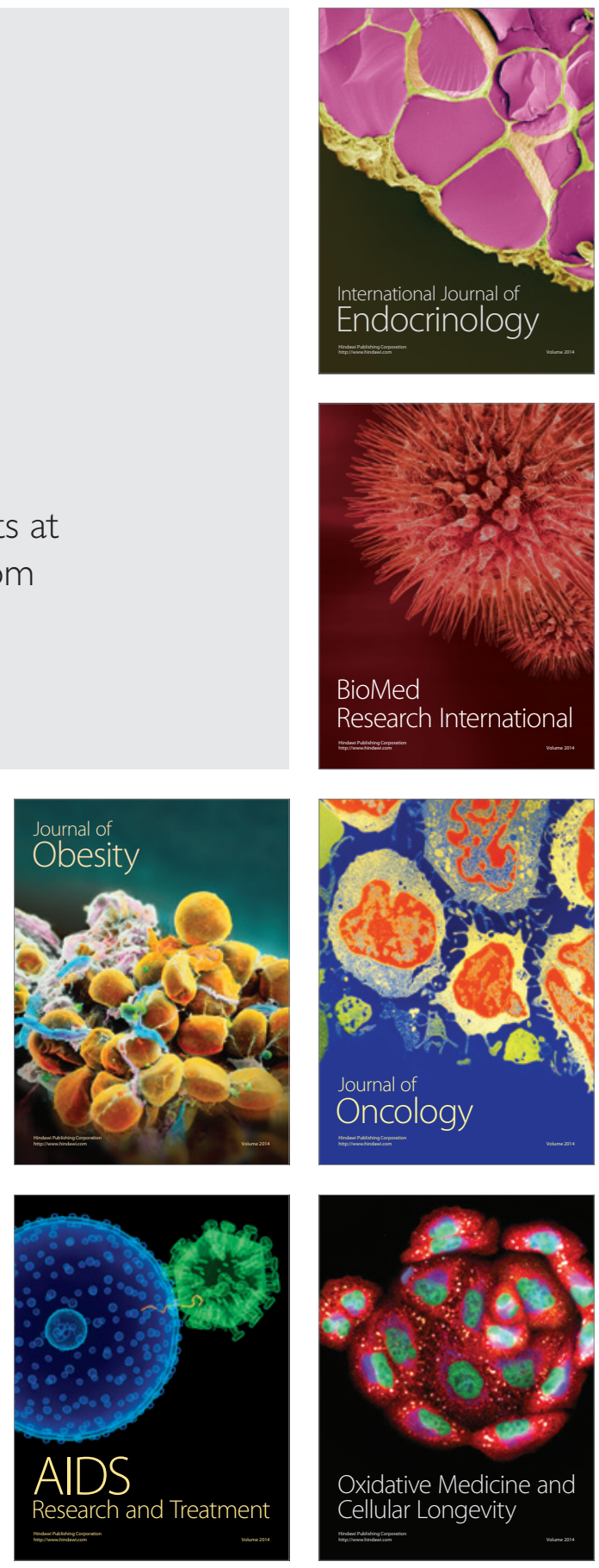